\title{
9th International Conference on Networked Sensing Systems (INSS 2012) 報告
}

篠田 裕之（東京大学）

今年の INSS (International Conference on Networked Sensing Systems）は 6 月 11 日から 14 日の 4 日間にわたり ベルギー アントワープで開催された。INSS はコンピュー タサイエンスをバックグラウンドとするネットワーク研究 者と MEMS をはじめとするセンシングデバイス・システム さらにはアプリケーションの研究者が一堂に会して議論を 行うことを特徴としており, 今年は第 9 回大会にあたる。 会議名からわかるとおり，センサのネットワークをどう作 るか，だけではなく，センサをネットワーク化することで 何ができるようになるのか, あるいはそのためにどのよう な要素技術開発が必要なのか，を考えることに重点が置か れている。初回は日本のグループが中心となって 2004 年に 東京で開催され, 以後米国, 欧州, アジアをまわりながら 今回はベルギー開催となった。

デモを含めた発表件数が 68 件の小規模な会議ではある が，フルペーパーの採択率は $30 \%$ に絞り込んであり，質の 高い講演が揃っている。また米国，欧州，日本で中心的な 役割を果たしている粒ぞろいの研究者が参加しており, さら に招待講演者も加わって毎年密度の濃い議論が行われる。 今年は Hans Gellersen, Sape Mullender による 2 件のキー ノートスピーチに加え, この分野を铱引する研究者 5 名が 招待され講演を行った。小規模なだけにランチやコーヒー ブレークのたびに議論を深めていくことができ, 参加者に とって満足度の高い会議となっている。6 月はアントワープ のベストシーズンであり, 会場近くにあるベル研究所での レセプション, バンケットクルーズなど, テクニカルプロ グラム以外の楽しみも多い会議であった。

発表論文の多くは, センサのネットワークを形成するた めの通信プロトコルの研究, センサをネットワーク化する ための物理的インフラとセンシングデバイスの研究, ネット ワークによって得られたデータから意味のある情報を抽出 する研究, それらのアプリケーションの研究, のいずれかに 分類される。センサノード間のマルチホップに関する通信 プロトコルの基礎研究が収束しつつある一方で, より上位 レイヤーのプラットフォームや, 人間の行動を環境が見守 り, 支援するシステム, 電力の有効利用をテーマとした研 究, ネットワークに流れるデータから個人およびその集団 の活動についての情報を抽出する方法などが活発に議論さ れた。以下は本会議口頭発表のセッションタイトルである。

1. Event Detection and Security

2. Human Sensing

3. Applications and Development Tools

4. Activity Recognition

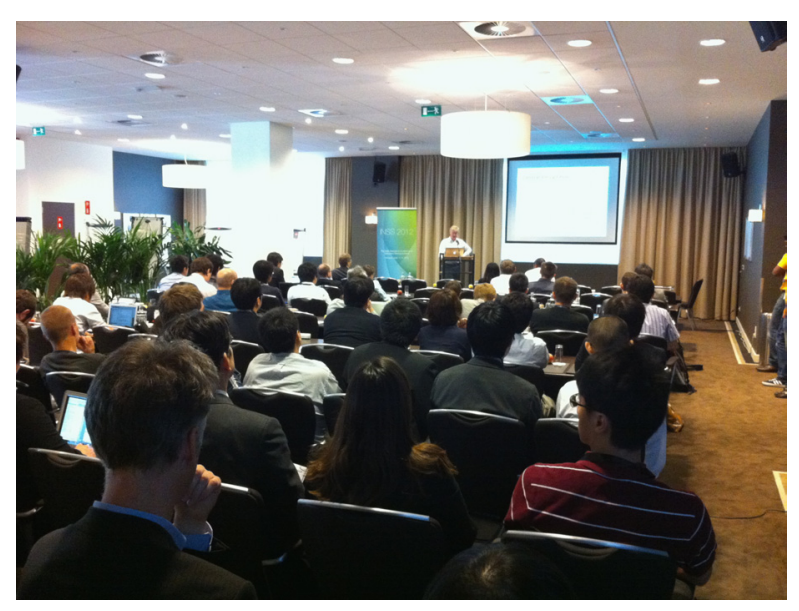

図 1 講演の様子

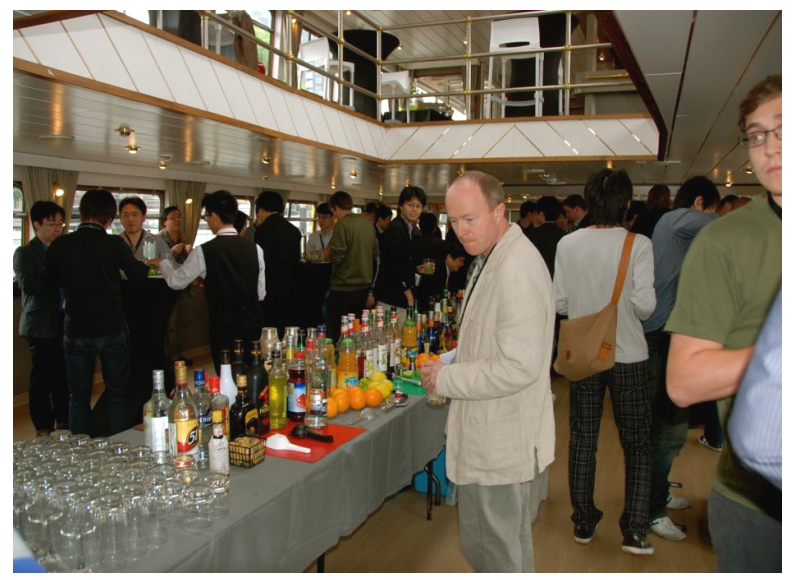

図 2 バンケットクルーズの様子

5. Novel Platforms

6. Practical Technologies

7. Novel Hardware

8. Networked Sensing Systems in Robotics

9. Innovations in Networking

10. Novel Protocol Design

ネットワークセンシングの技術は，省エネルギー，医療， 高齢化社会の人間支援, 広域的な人間の活動状況や自然環 境把握など, 今後の科学技術の主要課題や社会問題の解決 に貢献する基盤技術であるが, 漠然と基礎研究を進めるだ けでなく具体的なアプリケーションを強く意識し, 模索し ようとする参加者が多い点も本会議の特色である。

(平成 24 年 11 月 30 日受付) 